\title{
Urban Rainwater Harvesting Assessment in Sulaimani Heights District, Sulaimani City, KRG, Iraq
}

\author{
Kani Namiq Gharib, Nawbahar Faraj Mustafa, Haveen Muhammed Rashid \\ Department of Water Resources, College of Engineering, University of Sulaimani, KRG, Iraq
}

\section{A B S T R A C T}

Rainwater harvesting is the collection of rainwater and runoff from catchment areas such as roofs or other urban surfaces. Collected water has productive end-uses such as irrigation, industry, domestic, and can recharge groundwater. Sulaimani heights have been selected as a study area, which is located in Sulaimani Governorate in Kurdistan Region, North Iraq. The main objective of this study was to estimate the amount of harvested rainwater form Sulaimani heights urban area in Sulaimani City. Three methods for runoff calculation have been compared, the storm water management model (SWMM), the soil conservation service (SCS) method, and the runoff coefficient (RC) using daily rainfall data from 1991 to 2019. The annual harvested runoff results with the three different methods SWMM, SCS, and RC were estimated as $836,470 \mathrm{~m}^{3}$, $508,454 \mathrm{~m}^{3}$, and $737,381 \mathrm{~m}^{3}$, respectively. The results showed that SWMM method has the highest runoff result and could meet $31 \%$ of the total demand of the study area and $28 \%$ and $19 \%$ for RC and SCS methods, respectively.

Index Terms: Rainwater harvesting, Storm water management model, Soil conservation service, Runoff coefficient, Runoff, Sulaimani heights

\section{INTRODUCTION}

Water is crucial for urban sustainability and in maintaining the sustainability of the environment [1], [2]. The extreme urbanization, industrial development, and agricultural expansion lead to increase demand of water in many parts of the world [3], [4]. Urban area development continuously reduces the groundwater recharging areas and increases depletion of groundwater [5].

Rainwater harvesting (RWH) is the collection and concentration of rainwater and runoff from catchment areas such as roofs or

\begin{tabular}{|l|l|}
\hline \multicolumn{1}{|c|}{ Access this article online } \\
\hline DOI:10.21928/uhdjst.v5n1y2021.pp48-55 & $\begin{array}{l}\text { E-ISSN: 2521-4217 } \\
\text { P-ISSN: 2521-4209 }\end{array}$ \\
\hline $\begin{array}{l}\text { Copyright @ 2021 Rashid. This is an open access article distributed } \\
\text { under the Creative Commons Attribution Non-Commercial No } \\
\text { Derivatives License 4.0 (CC BY-NC-ND 4.0) }\end{array}$ \\
\hline
\end{tabular}

other urban structure and can be used for irrigation, industry, domestic, and for groundwater recharge purposes [6], [7], [8], [9]. RWH techniques have been used throughout time for the irrigation purpose by the ancient Iraqi people around 4500 $\mathrm{BC}[10]$, and it is an environmentally vocal decision to address issues brought out by large projects utilizing centralized water resources management approaches [11].

Many previous studies mentioned the use of RWH successfully as an effective and alternative water supply resolution [12], [13]. Patra and Gautam [4] conducted a study to assess the runoff coefficient (RC) method for RWH in Dhanbad city in India. The runoff results indicated that RH system is an economic option for where in the areas where rainfall is adequate and could supply part of the water demand of the city.

Zakaria et al., 2013 [14], used Macro RWH at Koysinjaq (Koya), in Kurdistan Region based on Soil Conservation Service Curve Number (SCS-CN) method. The findings

Corresponding author's e-mail: Nawbahar Faraj Mustafa, Department of Water Resources, College of Engineering, University of Sulaimani, KRG, Iraq. E-mail: nawbahar.mustafa@univsul,edu.iq

Received: 22-10-2020

Accepted: 25-04-2021

Published: 27-04-2021 
demonstrated that the macro-RWH method can be a new source of water to reduce the problem of water scarcity and to minimize the water shortages problem.

In a research conducted by Harb [9], different RWH techniques were evaluated to identify the most significant method for METU-NCC campus on the west of North Cyprus. The runoff from roofs, pervious and impervious areas were collected and utilized and applying in two approaches: Traditional SCS method and storm water management model (SWMM) RWHS for calculation of runoff volume and the findings could meet $41.2 \%$ of the campus irrigation demand.

In 2016, a paper published by Gnecco et al. [15] in which SWMM was used to investigate the effect of domestic RWH and storage unit effects on control efficiency. The study area was located in neighborhood in Albaro in Italy, where covers $6000 \mathrm{~m}^{2}$. The survey of the land use data displays that $57 \%$ of the land cover was impervious surfaces and 33\% of rooftops of the total area. The findings of the software pointed that RWH can be applied in in urban water management and methods for assessment and optimization of runoff storage and use as potable water.

\section{STUDY AREA}

The Sulaimani heights are located in Sulaimani Governorate in Kurdistan Region, North Iraq. The latitudes are between $35^{\circ} 35^{\prime} 55^{\prime \prime}$ 'and $35^{\circ} 36^{\prime} 51^{\prime \prime} \mathrm{N}$ and the longitudes are between $44^{\circ} 26^{\prime} 25^{\prime \prime}$ and $45^{\circ} 27^{\prime} 35^{\prime \prime} \mathrm{E}$. The area has a topographic with elevations ranged from $950 \mathrm{~m}$ to $1113 \mathrm{~m}$. Sulaimani has a mean annual rainfall of $715 \mathrm{~mm}$ and has a mean daily temperature of $19^{\circ} \mathrm{C}$ [16]. Sulaimani heights spread over an area of $2.12 \mathrm{~km}^{2}$ and containing 2899 units of various sizes. The study area consists of three subcatchments, as shown in Fig. 1, and the detail information about each subcatchment is shown in Table 1. According to the map from Sulaimani heights authority (Qaiwan Company), the area is divided into five zones, the green areas cover 17.14 $\%$ and the water pools cover $1.1 \%$ of the total area as shown in Fig. 2.

\section{MATERIALS AND METHODS}

\subsection{Data Sets and Data Collection}

\subsubsection{Climatology data}

The daily precipitation data for Sulaimani city from 1991 to 2019 were used from Directorate of Meteorology and Seismology of Sulaimani (DOMSOS). As there is no rain gauge station in the studied basins, therefore the closest meteorological station should be used; Sulaimani rain gauge in Ibrahim Pasha Street which is only $4 \mathrm{~km}$ away from the studied area that has an acceptable distance. Daily rainfall data were used to represent the basin rainfall for the study area [17].

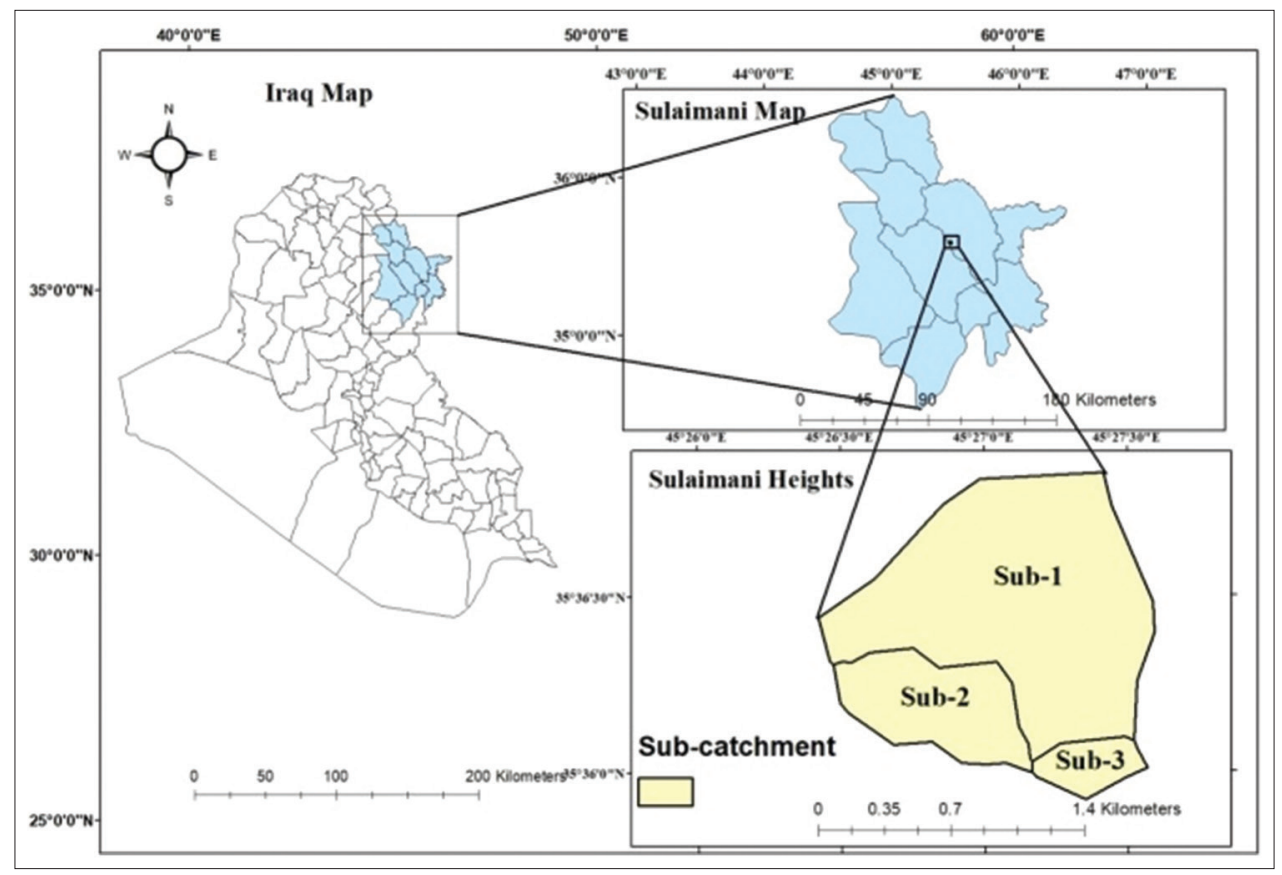

Fig. 1. Location of Sulaimani heights on Sulaimani map. 




Fig. 2. Land use of Sulaimani heights.

\section{TABLE 1: Detail information of the study area}

\begin{tabular}{lc}
\hline Parameter & Value \\
\hline Elevation $-\mathrm{m}$ & $915-1113$ \\
Area $\mathrm{km}^{2}$ & 2.12 \\
Zone No. & 5 \\
Subcatchment No. & 3 \\
Residential No. & 2899 \\
Mean annual rainfall $-\mathrm{mm}$ & 715 \\
Mean daily temperature $-{ }^{\circ} \mathrm{C}$ & 19 \\
\hline
\end{tabular}

Other climatology data which have effect on the volume of the runoff should be also considered [9]; the monthly average wind speed and pan evaporation data from 1991 to 2019 were obtained from the Directorate of Meteorology and Seismology of Sulaimani.

\subsubsection{Soil classification}

To find the common soil characteristics of the study area, the Harmonized World Soil Database Viewer (HWSD) version 1.21 and soil map of the area were used. The software is adopted by cooperation of the Food and Agriculture Organization of the United Nations (FAO), the Chinese Academy of Sciences (CAS), the International Institute for
Applied Systems Analysis (IIASA), the International Soil Reference and Information Centre (ISRIC), and the Joint Centre of the European Commission (JRC). The coordinates of the study area were pointed on the HWSD viewer software and the dominant soil group was found to be Chromic Vertisols with $100 \%$ light clay to be the most prominent soil textures. Therefore, the dominant soil texture is clay and hence this satisfies the Hydrologic Soil Group D [18].

\subsection{SWMIM}

SWMM is widely utilized software throughout the world in associating of urban runoff quantity and quality [19]. SWMM is a rainfall-runoff simulation model developed by the US Environmental Protection Agency to assist and support local storm water management in minimizing the runoff discharges. SWMM can forecast a single event or long-term (continuous) simulation set of model outputs parameters and inputs of runoff quantity and quality from primarily urban areas [20], [21], [22], [23], [24].

In accordance with the subcatchment properties, the average monthly surface runoff can be calculated through SWMM 
software, to estimate monthly results from the SWMM software, the dates of simulation should be manipulated from the Options tab and the software run gives runoff depth, infiltration depth, and runoff volumes in the form of a table.

SWMM uses the Manning equation to express the relationship between flow rate $(\mathrm{Q})$, cross-sectional area (A), hydraulic radius $(\mathrm{R})$, and slope $(\mathrm{S})$ in all conduits [21], [25].

For standard S.I units:

$$
\mathrm{Q}=\frac{1}{\mathrm{n}} \mathrm{AR}^{\frac{2}{3}} \mathrm{~S}^{\frac{1}{2}}
$$

Where, $\mathrm{n}$ is the manning roughness coefficient. The slope $\mathrm{S}$ stands for either the conduit slope or the friction slope (i.e. head loss per unit length), depending on the flow routing method used. The $\mathrm{R}$ is hydraulic radius, which is fraction of area to wetted parameter of the conduit or the channel.

\subsection{Traditional SCS Method}

SCS method is another suitable method for this case, as it includes all types of abstractions in the runoff calculation and the parameters needed for runoff estimation. The runoff volumes will be estimated based on SCS-CN method. CN method is thoroughly used for estimating direct runoff volume for a particular rainfall event [26], [27]. For the SCS, 1972 (SCS-CN) method, the CN(I) stands for dry condition, $\mathrm{CN}$ (III) stands for wet condition and tabulated $\mathrm{CN}$ is equal to $\mathrm{CN}$ (II), for normal (average) conditions, and can be modified for dry and wet conditions, as explained by Chow et al. [28] through the following Equations 2 and 3 [29]:

$$
\begin{aligned}
& \mathrm{CN}(\mathrm{I})=\frac{4.2 * \mathrm{CN}_{\mathrm{II}}}{10-0.058 * \mathrm{CN}_{\mathrm{II}}} \\
& \mathrm{CN}(\mathrm{III})=\frac{23 * \mathrm{CN}_{\mathrm{II}}}{10+0.13 * \mathrm{CN}_{\mathrm{II}}}
\end{aligned}
$$

The expression used in SCS method for estimating runoff can be calculated through Equation 4 [18]:

$$
Q=\frac{\left(P-I_{a}\right)^{2}}{\left\{\left(P-I_{a}\right)+S\right\}}
$$

Where, Q is the accumulated storm runoff in $(\mathrm{mm})$; $\mathrm{P}$ is accumulated storm rainfall in $(\mathrm{mm}), \mathrm{S}$ is potential maximum retention of water by the soil, $\mathrm{I}_{\mathrm{a}}$ is initial quantity of interception, infiltration, and depression which can be quantified through Equation 5.

$$
S=\frac{25400}{C N}-254
$$

While the data needed to calculate the runoff volume are present, SCS method is also used to compute the runoff volume. The runoff depth from subcatchments is calculated using $\mathrm{CN}$ and rainfall depth. After the runoff depth is calculated, the volume of the runoff from each subcatchment is computed by multiplying the area of each subcatchment as shown in Equation 6.

$$
\mathrm{V}=\mathrm{R}^{*} \mathrm{~A}
$$

Where, $V$ is the volume of runoff $\left(\mathrm{m}^{3}\right) ; R$ is the rainfallrunoff $(m)$; and $A$ is the area of the subcatchment $\left(\mathrm{m}^{2}\right)$.

\subsection{Assessment of RC}

$\mathrm{RC}$ for any catchment is the ratio of the volume of water that runs off a surface to the volume of rainfall that falls on the surface [30].

The Rc takes into account any losses due to evaporation, leakage, surface material texture overflow, transportation, and inefficiencies in the collection process [17]. The RWH potential or volume of water received from a given catchment can be obtained using the following Equation 7 [17].

$$
\mathrm{V}_{\mathrm{r}}=\mathrm{RA}_{\mathrm{c}} \mathrm{R}_{\mathrm{c}}
$$

Where, $\mathrm{V}_{\mathrm{r}}$ the monthly volume of rainwater, $\mathrm{R}$ is average monthly rainfall depth, $A_{c}$ is area of the catchment, and $R_{c}$ runoff coefficient.

To calculate the monthly runoff produced for each subcatchment, RCs (Equation 7) is used. The average $R_{C}$ for the different types of areas was selected [31], for the areas of constructed concrete and asphalt, the $\mathrm{R}_{C}$ was selected as 0.65, 0.075 for green area, and 0.9 for water bodies.

The flowchart in Fig. 3 shows the steps followed for the calculation of runoff using the mentioned three methods.

\subsection{Water Demand}

To determine domestic water demand for indoor and outdoor household purposes, the standard average daily water demand per capita (Sulaimani water supply directorate) which is (250 $1 /$ capita/day) is used to calculate the average monthly demand for the study area [32]. Harvested rainwater should be treated before using for drinking purpose [33]. In accordance with the study area, there are 2899 residential and the average of 5 members in a household counted to estimate the total water demand for the study area. The total population of the study area calculated and the total daily water demand found for Sulaimani Heights. Using the map of the study area, the areas for each type of vegetation group for the study area 
are calculated in AutoCAD and the irrigation months were selected with the amount of water for each $\mathrm{m}^{2}$ of vegetation area. Thus, the monthly demands for the study area calculated by multiplying the number of days of the month and then by the total daily demand. The results of water demands are shown in Tables 2-5.

\section{RESULTS AND DISCUSSION}

The results from the three models are shown in Table 6 which shows that the SWMM method has the largest annual runoff volume of $836,470 \mathrm{~m}^{3}$, Rc method results with $737,381 \mathrm{~m}^{3}$ and SCS method with 508,454 $\mathrm{m}^{3}$ for the average annual rainfall of $719 \mathrm{~mm}$. Table 7 and Table 8 represent the monthly and annual water demand, respectively, with the corresponding percent demand met.

The results showed that SWMM method has the highest runoff result and could meet $31 \%$ of the total demand of the study area and 28\% and 19\% for Rc and SCS methods, respectively. Comparison between respective runoff results clearly demonstrates that the runoff results are influencing by the serial urbanization [34].

\section{TABLE 2: Total daily domestic water demand in} Sulaimani heights

\begin{tabular}{lccc}
\hline $\begin{array}{l}\text { Sub. } \\
\text { No. }\end{array}$ & $\begin{array}{c}\text { No. of } \\
\text { residence }\end{array}$ & Population & $\begin{array}{c}\text { Water demand } \\
\left(\mathbf{m}^{3} / \text { day }\right)\end{array}$ \\
\hline 1 & 2541 & 12,705 & 3176 \\
2 & 358 & 1790 & 448 \\
3 & 0 & 0 & 0 \\
Total & 2899 & 14,495 & 3624 \\
\hline
\end{tabular}

\section{TABLE 3: Vegetation area and type of each subcatchment}

\begin{tabular}{lccc}
\hline Subcatchment & $\begin{array}{c}\text { Green } \\
\text { area }\left(\mathbf{m}^{2}\right)\end{array}$ & \multicolumn{2}{c}{ Crop type } \\
\cline { 3 - 4 } & $\begin{array}{c}\text { Ground } \\
\text { cover } \\
\text { area }\left(\mathbf{m}^{2}\right)\end{array}$ & $\begin{array}{c}\text { Trees and } \\
\text { bushes } \\
\text { area }\left(\mathbf{m}^{2}\right)\end{array}$ \\
\hline Sub-1 & 447,182 & 302,080 & 145,102 \\
Sub-2 & 50,087 & 42,070 & 8017 \\
Sub-3 & 127,650 & 108,400 & 19,250 \\
Total area $\left(\mathrm{m}^{2}\right)$ & 624,919 & 452,550 & 172,369 \\
\hline
\end{tabular}

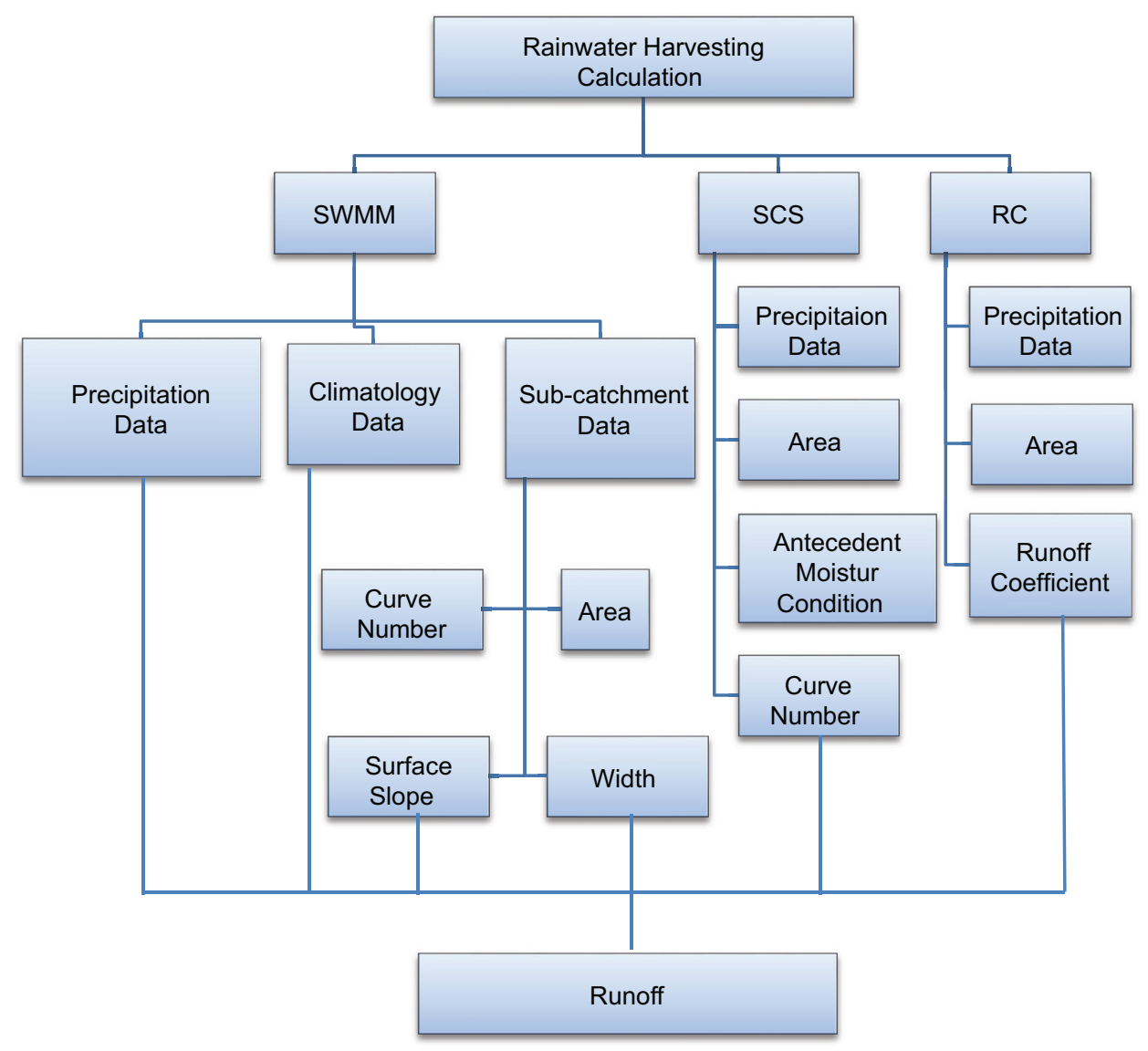

Fig. 3. Flowchart summary for runoff calculation methods. 
Gharib, et al.: Urban Rainwater Harvesting

TABLE 4: Total monthly irrigation water demand in Sulaimani heights

\begin{tabular}{|c|c|c|c|c|c|c|}
\hline \multirow[t]{2}{*}{ Crop type } & \multirow[t]{2}{*}{ Month of irrigation } & \multirow{2}{*}{$\begin{array}{l}\text { Irrigation period } \\
\text { (day/month) }\end{array}$} & \multirow{2}{*}{$\begin{array}{l}\text { Required water } \\
\text { per }\left(m^{2}\right)(L / \text { day })\end{array}$} & \multicolumn{3}{|c|}{ Water demand ( $\mathrm{m}^{2} /$ month) } \\
\hline & & & & Sub-1 & Sub-2 & Sub-3 \\
\hline \multirow[t]{5}{*}{ Ground cover } & May & 15 & 12 & $54,374.40$ & 7572.60 & $19,512.00$ \\
\hline & June & 30 & 16 & $144,998.40$ & $20,193.60$ & $52,032.00$ \\
\hline & August & 31 & 16 & $149,831.68$ & $20,866.72$ & $53,766.40$ \\
\hline & September & 30 & 16 & $144,998.40$ & $20,193.60$ & $52,032.00$ \\
\hline & October & 15 & 12 & $54,374.40$ & 7572.60 & $19,512.00$ \\
\hline \multirow{4}{*}{ Trees and bushes } & July & 31 & 12 & $53,977.94$ & 2982.32 & 7161.00 \\
\hline & August & 31 & 12 & $53,977.94$ & 2982.32 & 7161.00 \\
\hline & September & 30 & 12 & $52,236.72$ & 2886.12 & 6930.00 \\
\hline & October & 15 & 8 & $17,412.24$ & 962.04 & 2310.00 \\
\hline
\end{tabular}

TABLE 5: Total demand in the three subcatchments

\begin{tabular}{|c|c|c|c|c|c|}
\hline \multirow[t]{2}{*}{ Month } & \multirow[t]{2}{*}{ No. of days } & \multicolumn{3}{|c|}{ Water demand ( $\mathrm{m}^{2} /$ month) } & \multirow[t]{2}{*}{ Total water demand ( $\mathrm{m}^{3} /$ month) } \\
\hline & & Sub-1 & Sub-2 & Sub-3 & \\
\hline January & 31 & 98,456 & 13,888 & 0 & 112,344 \\
\hline February & 28 & 88,928 & 12,544 & 0 & 101,472 \\
\hline April & 30 & 95,280 & 13,440 & 0 & 108,720 \\
\hline May & 31 & $170,242.6$ & $22,422.64$ & 21,822 & $214,487.28$ \\
\hline June & 30 & $292,515.1$ & $36,519.72$ & 58,962 & $387,996.84$ \\
\hline September & 30 & $292,515.1$ & $36,519.72$ & 58,962 & $387,996.84$ \\
\hline October & 31 & $170,242.6$ & $22,422.64$ & 21,822 & $214,487.28$ \\
\hline November & 30 & 95,280 & 13,440 & 0 & 108,720 \\
\hline December & 31 & 98,456 & 13,888 & 0 & 112,344 \\
\hline Total & 365 & $2,104,903$ & 274,447 & 283,423 & $2,662,772$ \\
\hline
\end{tabular}

TABLE 6: The runoff volume results of the three methods

\begin{tabular}{|c|c|c|c|c|}
\hline Month & $\begin{array}{c}\text { Sum of average } \\
\text { monthly rainfall }(\mathrm{mm})\end{array}$ & $\begin{array}{l}\text { Volume of runoff by } \\
\text { SWMM ( }{ }^{3} / \text { month) }\end{array}$ & $\begin{array}{l}\text { Volume of runoff } \\
\text { by SCS ( } \mathrm{m}^{3} / \text { month) }\end{array}$ & $\begin{array}{l}\text { Volume of runoff } \\
\text { by } \mathrm{Rc}\left(\mathrm{m}^{3} / \mathrm{month}\right)\end{array}$ \\
\hline January & 119.43 & 150,040 & $76,912.01$ & $122,350.48$ \\
\hline February & 116.84 & 149,720 & $90,680.95$ & $119,697.14$ \\
\hline April & 96.53 & 111,190 & $53,480.01$ & $98,890.49$ \\
\hline May & 41.84 & 33,620 & $25,415.88$ & $42,863.13$ \\
\hline June & 0 & 0 & 0 & 0 \\
\hline September & 0 & 0 & 0 & 0 \\
\hline October & 44.43 & 41,920 & $53,829.71$ & $45,516.47$ \\
\hline November & 81.84 & 87,510 & $58,195.91$ & $83,841.27$ \\
\hline December & 113.76 & 138,150 & $80,271.92$ & $116,541.83$ \\
\hline Total & 719.78 & 836,470 & $508,453.71$ & 737,381 \\
\hline
\end{tabular}

SWMM: Storm water management model, SCS: Soil conservation service, RC: Runoff coefficient

From the methods discussed previously, it appears that the traditional SCS method and assessment of RC are respectable to be a combined with more losses method since the initial abstraction includes infiltration, evaporation, interception, and surface texture caused by these processes are calculated simultaneously [9], [35]. 
TABLE 7: Monthly water demand and corresponding percent demand met

\begin{tabular}{|c|c|c|c|c|c|c|c|c|c|}
\hline \multirow[t]{2}{*}{ Month } & \multicolumn{3}{|c|}{$\begin{array}{c}\text { Percent of water demand met } \\
\text { using SWMM (\%) }\end{array}$} & \multicolumn{3}{|c|}{$\begin{array}{c}\text { Percent of water demand met } \\
\text { using SCS (\%) }\end{array}$} & \multicolumn{3}{|c|}{$\begin{array}{l}\text { Percent of water demand met } \\
\text { sing RC (\%) }\end{array}$} \\
\hline & Sub-1 & Sub-2 & Sub-3 & Sub-1 & Sub-2 & Sub-3 & Sub-3 & Sub-2 & Sub-3 \\
\hline October & 18 & 44 & 5 & 23 & 49 & 16 & 20 & 50 & 2 \\
\hline December & 100 & 100 & 100 & 57 & 100 & 100 & 88 & 100 & 100 \\
\hline January & 100 & 100 & 100 & 54 & 100 & 100 & 92 & 100 & 100 \\
\hline February & 100 & 100 & 100 & 71 & 100 & 100 & 100 & 100 & 100 \\
\hline May & 15 & 36 & 4 & 10 & 27 & 8 & 19 & 47 & 2 \\
\hline June & 0 & 0 & 0 & 0 & 0 & 0 & 0 & 0 & 0 \\
\hline July & 0 & 0 & 0 & 0 & 0 & 0 & 0 & 0 & 0 \\
\hline August & 0 & 0 & 0 & 0 & 0 & 0 & 0 & 0 & 0 \\
\hline September & 0 & 0 & 0 & 0 & 0 & 0 & 0 & 0 & 0 \\
\hline
\end{tabular}

SWMM: Storm water management model, SCS: Soil conservation service, RC: Runoff coefficient

TABLE 8: Annual water demand and corresponding percent demand met

\begin{tabular}{lccc}
\hline Method & SWMM & SCS & RC \\
\hline Runoff $\left(\mathrm{m}^{3}\right)$ & 836,470 & 508,454 & 737,381 \\
Annual demand $\left(\mathrm{m}^{3}\right)$ & $2,662,772$ & $2,662,772$ & $2,662,772$ \\
Annual demand met \% & 31 & 19 & 28 \\
\hline
\end{tabular}

SWMM: Storm water management model, SCS: Soil conservation service, RC: Runoff coefficient

In addition, in the SCS and Rc methods, the infiltration in the initial abstraction does not change with rainfall events variation on a subcatchment, conversely, it would stay the same before and during the rainfall event [9], [35]. Some parameters implied in the SWMM model but not computed in the SCS such as the depression storage, percent of impervious layer, the pervious roughness coefficient, and the soil drying time [9], [21], [24].

On the other hand, the SWMM model has flexibility to route runoff and external inflows through the drainage systems, and the abstractions such as evaporation and infiltration vary with changing rainfall events [20]. Due to these limitations, the SWMM model is established in the prediction of comparable runoffs [36].

The SWMM differs from the SCS and Rc approaches by that the SWMM model can perform helpful and time saver tool in designing large catchments and SWMM has better feasibility of determining peak flow and volume of runoff with in the nodes and pipes for designing urban drainage system [21], [24].

\section{CONCLUSION}

This research studied the feasibility of applying RWH techniques as a water resource that should be associated into the management of urban areas. RWH for different types of catchments such as roofs, roads, and open areas has been founded. Three approaches for runoff calculation were adopted, the SWMM, the traditional SCS method, and the RC. Daily rainfall data from 1991 to 2019 were used to obtain the monthly and annual volume. Moreover, to demonstrate the potential RWH system, the annual demand for the study area was found and compared with the total annual runoff volume using three methods, however, harvested rainwater harvested should be treated before using for drinking purpose.

For the estimated total yearly water demand in the study area of demand in the study area of 2,662,772 $\mathrm{m}^{3}$, the annual runoff results with the methods SWMM, SCS, and Rc were estimated of $836,470 \mathrm{~m}^{3}, 508,454 \mathrm{~m}^{3}$ and $737,381 \mathrm{~m}^{3}$ respectively. The final results showed that SWMM method has the highest runoff result and could meet $31 \%$ of the total demand of the study area and $28 \%$ and $19 \%$ for Rc and SCS methods, respectively.

\section{ACKNOWLEDGMENT}

I truly want to thank Qaiwan Group for assistance in complimenting this study and my family for their support and guidance. 


\section{REFERENCES}

[1] A. Daoud, K. Swaileh, R. M. Hussein and M. Matani. "Quality Assessment of Roof-harvested Rainwater in the West Bank, Palestinian Authority". Journal of Water and Health, vol. 9, pp. 525-533, 2011.

[2] T. M. Pinzón. "Modelling and Sustainable Management of Rainwater Harvesting in Urban Systems". Theses, 2013.

[3] U. WWDR. Water and Energy, the United Nations World Water Development Report 2014 (2 volumes). UN World Water Assessment Programme, Unesco, Paris. Available from: https://sustainabledevelopment.un.org/content/ documents/1714Water\%20Development\%20Report\%202014.pdf. [Last accessed on 2019 Mar 19].

[4] A. K. Patra and S. Gautam. "A pilot scheme for rooftop rainwater harvesting at Centre of Mining Environment, Dhanbad". International Journal of Environmental Sciences, vol. 1, pp. 1542-1548, 2011.

[5] S. N. Baby, C. Arrowsmith and N. Al-Ansari. "Application of GIS for mapping rainwater-harvesting potential: Case study Wollert, Victoria”. Engineering, vol. 11, pp. 14-21, 2019.

[6] K. Subagyono and H. Pawitan. "Water Harvesting Techniques for Sustainable Water Resources Management in the Catchment Area". In: Proceedings of International Workshop on Integrated Watershed Management for Sustainable Water Use in a Humid Tropical Region, Tsukuba, 2008, pp. 18-30.

[7] D. Prinz, T. Oweis and A. Hachum. "The Concept, Components, and Methods of Rainwater Harvesting". In: $2^{\text {nd }}$ Arab Water Forum Living With Water Scarcity, Cairo, 2011, pp. 1-25.

[8] C. Bari. "Emerging Practices from Agricultural Water Management in Africa and the Near East". Thematic Workshop, 2017.

[9] R. Harb. "Assessing the Potential of Rainwater Harvesting System at the Middle East Technical University-Northern Cyprus Campus". Middle East Technical University Library. Available from: http://www.etd.lib.metu.edu.tr/upload/12619225/index.pdf. [Last accessed on 2016 Nov 10].

[10] R. H. Handbook. "Assessment of Best Practises and Experience in Water Harvesting". African Development Bank, Abidjan, 2001.

[11] J. Julius, R. A. Prabhavathy and G. Ravikumar. "Rainwater harvesting (RWH)-A review". International Journal of Innovative Research and Development, vol. 2, p. 925, 2013.

[12] G. Freni and L. Liuzzo. "Effectiveness of rainwater harvesting systems for flood reduction in residential urban areas". Water, vol. 11, p. 1389, 2019.

[13] I. A. Alwan, N. A. Aziz and M. N. Hamoodi. "Potential water harvesting sites identification using spatial multi-criteria evaluation in Maysan Province, Iraq". ISPRS International Journal of GeoInformation, vol. 9, p. 235, 2020.

[14] S. Zakaria, N. Al-Ansari, Y. Mustafa, S. Knutsson, P. Ahmed and B. Ghafour. "Rainwater harvesting at Koysinjaq (Koya), Kurdistan Region, Iraq". Journal of Earth Sciences and Geotechnical Engineering, vol. 3, pp. 25-46, 2013.

[15] I. Gnecco, A. Palla and P. La Barbera. "The role of domestic rainwater harvesting systems in storm water runoff mitigation". Eur Water, vol. 58, pp. 497-503, 2017.

[16] N. F. Mustafa, H. M. Rashid and H. M. Ibrahim. "Aridity Index Based on Temperature and Rainfall Data for Kurdistan RegionIraq". Journal of Duhok University, vol. 21, pp. 65-80, 2018.

[17] J. Worm. "AD43E Rainwater Harvesting for Domestic Use".
Agromisa Foundation, 2006.

[18] Z. Ara and M. Zakwan. "Estimating runoff using SCS curve number method". International Journal of Emerging Technology and Advanced Engineering, vol. 8, pp. 195-200, 2018.

[19] J. Gironás, L. A. Roesner, L. A. Rossman and J. Davis. "A new applications manual for the Storm Water Management Model (SWMM)". Environmental Modelling and Software, vol. 25, pp. 813-814, 2010.

[20] W. R. C. James and L. A. Rossman. "User's Guide to SWMM 5". Computational Hydraulics International, 2010.

[21] L. A. Rossman. "Storm Water Management Model User's Manual, Version 5.0". National Risk Management Research Laboratory, Cincinnati, 2010.

[22] J. Nipper. "Measurement and Modeling of Stormwater from Small Suburban Watersheds in Vermont". Theses, 2016.

[23] S. Agarwal and S. Kumar. "Applicability of SWMM for semi urban catchment flood modeling using extreme rainfall events". The International Journal of Recent Technology and Engineering, vol. 8, pp. 245-251, 2019.

[24] M. Waikar and U. Namita. "Urban flood modeling by using EPA SWMM 5". SRTM University's Research Journal of Science, vol. 1, p. 20, 2015.

[25] H. Tikkanen. "Hydrological Modeling of a Large Urban Catchment Using a Stormwater Management Model (SWMM), Thesis, 2013.

[26] R. H. Hawkins, T. J. Ward, D. E. Woodward and J. A. Van Mullem. "Curve Number Hydrology: State of the Practice". American Society of Civil Engineers, 2008.

[27] A. Bansode and K. Patil. "Estimation of runoff by using SCS curve number method and arc GIS". International Journal of Scientific and Engineering Research, vol. 5, pp. 1283-1287, 2014.

[28] V. Chow, D. Maidment and W. L. Mays. "Applied Hydrology". MacGraw-Hill," Inc., New York, p. 149, 1988.

[29] N. Al-Ansari, S. Knutsson, S. Zakaria and M. Ezz-Aldeen. "Feasibility of Using Small Dams in Water Harvesting, Northern Iraq". In: ICOLD Congress 2015: International Commission on Large Dams 15/06/2015-16/07/2015, 2015.

[30] M. Awawdeh, S. Al-Shraideh, K. Al-Qudah and R. Jaradat. "Rainwater harvesting assessment for a small size urban area in Jordan". International Journal of Water Resources and Environmental Engineering, vol. 4, pp. 415-422, 2012.

[31] G. Dadhich and P. Mathur. "A GIS based analysis for rooftop rain water harvesting". International Journal of Computer Science and Engineering Technology, vol. 7, pp. 129-143, 2016.

[32] K. N. Sharief. "Water Supply Management of the Sulaymaniyah City". Unpublished PhD Thesis, University of Duhok, p. 24, 2013.

[33] C. A. Novak, E. Van Giesen and K. M. DeBusk. "Designing Rainwater Harvesting Systems: Integrating Rainwater into Building Systems". John Wiley and Sons, Hoboken, New Jersey, 2014.

[34] R. N. Eli and S. J. Lamont. "Curve Numbers and Urban Runoff Modeling Application Limitations". In: Low Impact Development 2010: Redefining Water in the City, pp. 405-418, 2010.

[35] D. A. Size. "Computing Stormwater Runoff Rates and Volumes". New Jersey Storm water Best Management Practices, pp. 5-22, 2004.

[36] G. R. Ghimire, R. Thakali, A. Kalra and S. Ahmad. "Role of Low Impact Development in the Attenuation of Flood Flows in Urban Areas". World Environmental and Water Resources Congress, pp. 339-349, 2016. 